AIDS

\title{
US plan for foundation in trouble with French
}

\section{Washington}

THE United States has announced its intention to create an international foundation to promote research into acquired immune deficiency syndrome (AIDS). Health and Human Services Secretary Otis Bowen made the announcement in a speech to the 39th World Health Assembly last week in Geneva, Switzerland.

Bowen's speech was delivered just days after an apparent breakdown in negotiations between the Pasteur Institute and the US Department of Health and Human Services (HHS) to resolve the legal dispute over the patent of the blood test for AIDS. A lawyer for the Pasteur in Washington claimed that a similar plan for an international foundation had been suggested by HHS lawyers as a basis for settling the dispute.

In a press release issued last week before Bowen's speech, Pasteur Institute director Raymond Dedonder claimed that the US government was moving toward awarding the blood test patent to the Pasteur Institute, and accused HHS of "making a public relations gesture rather than facing the reality of the situation". On 29 April, the US Patent and Trademark Office agreed to investigate whether the Pasteur patent should take precedence over the patent already awarded to Robert Gallo and his colleagues at the US National Institutes of Health (NIH) for the AIDS blood test (see Nature 321, 102; 1986).

A spokesman for HHS maintained that negotiations were still going on with the Pasteur to settle the patent issue. But according to a lawyer for the Pasteur Institute, HHS informed Pasteur's lawyers on 2 May that if they did not agree to go along with the international foundation, HHS would proceed unilaterally with the idea.

As originally formulated, the proposed foundation would support basic research on retroviruses, with special emphasis on the virus causing AIDS. A nine-member board would select research projects for funding. The board would consist of three members each from the United States and France and three additional members from other countries chosen by the initial six. Acting Assistant Secretary of HHS Donald Macdonald said in an interview that there were still a lot of "loose ends to be tucked in", but he confirmed that potential board members have been contacted and papers of incorporation have been drawn up. Macdonald said he hoped that a final decision to go ahead with the foundation could come by the middle of June.
But Macdonald explicitly denied the suggestion that the foundation proposed by Bowen was linked to settling the patent dispute. He claimed it was a "unilateral action to encourage international cooperation", and would not require French agreement.

Caroline Chaine, speaking for the $\mathrm{Pa}$ steur Institute, said the institute could not go along with the foundation idea because it would "take monies to which we have rights". She described the proposal as "unacceptable" for financial, legal and "ethical" reasons - because the Pasteur had after all made the discovery of the AIDS virus and offered the compromise of sharing royalties.

The stakes in the patent dispute are high. In addition to the prestige of the researchers and institutions involved, the US Department of Commerce estimates that the patent currently held by the United States is generating revenue at the rate of $\$ 2$ million per year. That figure could grow substantially if blood tests become more widely used. While $\$ 2$ million represents a small fraction of NIH's current budget for AIDS research, it is approximately two-thirds of the Pasteur's 1985 AIDS budget.

\section{French science}

\section{Research gives place to projects}

THE powerful new French ministry of finance is dictating terms to the ministry of research, it emerged last week. In the process, the ministry seems to be going far beyond its traditional role into the detailed examination of research policy and perhaps even beyond its competence.

The case in point is the budget of the principal body supporting basic science in France, the Centre National de la Recherche Scientifique (CNRS), which has fallen by 10 per cent in the cuts recently imposed on research by the new government. CNRS would normally have expected to make its own decisions about the allocation of the cuts, but the hard choices made by its council last week have had to be referred back to the ministry.

CNRS at its meeting last week decided that it would protect its laboratories' working budgets for materials and equipment. The council therefore elected to produce the bulk of the FF230 million ( $£ 23$ million) savings forced on it by the government in the form of 25 per cent cuts in special programmes and 20 per cent in spending on equipment and buildings. This left only 7.5 per cent (FF80-90 million) to be shaved off research budgets.

It seems, however, that the finance ministry has said no, and demanded a cut of at least 10 per cent in the laboratory budgets, which would mean savings of another FF30 million. This would mean, in turn, that less would have to be removed from the special programme or building budget, but that seems hardly to be the real issue, which is whether it is CNRS and the ministry of research and higher education that are controlling research policy, or the ministry of finance.

Meanwhile, scientific hackles are also being raised in some quarters at the preferential treatment being meted out to some of France's big technological programmes, notably space development, which is at present sustained by the success of the Ariane space launcher, fullybooked far into the future, with the SPOT Earth-observation satellite now fully operational and with plans for Hermes, a European mini-shuttle 50 per cent financed by France, looking stronger after West Germany last week indicated its likely commitment to the project.

Hermes, less ambitious than the US space shuttle, is likely to cost some FF15,000 million ( $£ 1,500$ million). That, however, is money yet to be spent, and details of the 1986 spending of the Centre National d'Études Spatiales (CNES), the French national space agency, published last week, already demonstrate dramatic increases agreed by the previous socialist government and which have not been touched by the new conservative government.

The 1986 CNES budget is up more than 25 per compared with 1985 . with most of that increase from public funds, to reach a figure of FF6,042 million this year. By far the greatest part of this comes in the form of direct technological programmes, including SPOT, telecommunications and direct broadcast satellites, together with the development of advanced versions of Ariane. Scientific experiments per se, many of them in cooperation with the Soviet Union, will cost CNES just FF185 million, only 3 per cent of its total budget this year.

However, this concentration of technological "great programmes" (such as nuclear power, the European Airbus, the high speed train, and space) is fully within the French tradition and even continued under the previous socialist government. Under the new, right-wing government, the tradition largely in the hands of the élite French engineers is emerging unscathed, while the basic science is suffering.
Robert Walgate 